\title{
50 years, thousands of papers, a changing future
}

\author{
Judit Szendrői ${ }^{1} \cdot$ Eszter Szücs $^{1} \cdot$ Viktor Wesztergom $^{1}$
}

Published online: 29 October 2015

(C) Akadémiai Kiadó 2015

Dear Reader,

As it was announced at the beginning of 2015 Acta Geodaetica et Geophysica (AGG) is celebrating the 50 years anniversary of its foundation. It is an exceptional occasion to look back to the evolution, to evaluate the present status and also to assess future tasks and challenges that we are facing.

The predecessor of AGG, Acta Geodaetica Geophysica et Montanistica Academiae Scientiarum Hungaricae was founded by the Hungarian Academy of Sciences in the frame of the academic mission of propagating domestic scientific results abroad and promotion of international connections of the Hungarian scientists. Thanks to the exceptional international character of the disciplines of geodesy and geophysics and also to the right propagation policy-namely providing exchange copies for many universities, libraries and research institutes for many years - the journal has been well-known from an early stage. It attracted many of the most prominent contemporary scientists worldwide and became a relevant international forum on geodesy especially research related to figure of the Earth, on geomagnetism and on electromagnetic investigation of the Earth's interior. Author names like Ledersteger, Barvir, Rinner, Wolf, Meissl, Isotov, Hristov, Bossolasco, Böhm, Fanselau, Korschunow, Le Minh Triet, Bouska, Troitskaya, Porstendorfer, Fournier, Berdichevsky, Lipskaya, Kovtun, Hutton clearly demonstrate the historical internationality. However a

Judit Szendrői

szendroi@ggki.hu

Eszter Szücs

szucs_e@ggki.hu

Viktor Wesztergom

wv@ggki.hu

1 Geodetic and Geophysical Institute, Research Centre for Astronomy and Earth Sciences, Hungarian Academy of Sciences, Sopron, Hungary 
certain national character was kept in the dominancy of Hungarian authors and reporting local celebrations, obituaries until the late nineties.

This character has fully disappeared during the transition period between 2000 and 2013. Since then AGG publishes only high quality original research in the fields of geodesy and geophysics and also offers thematic issues on exciting topics. The Journal is abstracted and indexed by important databases and occupies a stable position among the traditional journals of the geodesy and geophysics.

The past two decades brought sudden and dramatic changes in scientific publication. Dynamic expansion of electronic media, invasion of online journals, appearance of different databases offering easy access to papers and the parallel changing habit of the readers in getting information are clear tendencies. As a consequence the role of print media is also changing from dissemination of knowledge to ranking, certification of research and highlighting the excellence. We do hope that the interesting topics, huge number of submissions therefore the possibility of selection, and careful, responsible review process together ensure the future of AGG for many more decades.

We say thanks first of all our readers, authors, reviewers, advisors, handling editors and friends, everyone who has put effort, heart and soul into our common success and accomplishment of ongoing purposes.

Thanks are also due to the Hungarian Academy of Sciences for the continuous support and encouragement, to the Publishers (Akadémiai Kiadó and Springer) for guidance and expertise, and to the Geodetic and Geophysical Institute for hosting the Journal. 